\title{
Entre o atlântico e a costa: confluência de rotas mercantis num porto periférico da América portuguesa (Santos, 1808-1822)
}

\author{
Denise Moura[1]
}

\begin{abstract}
Resumo
Este artigo discute o caráter costeiro e atlântico da atividade mercantil no porto de Santos entre 1808 e 1822 e as contradições oriundas desta dupla condição, única na costa Sul da América portuguesa. Esta discussão foi fundamentada em dados levantados nos mapas de importação e exportação produzidos pela alfândega de Santos para a Real Junta de Comércio.
\end{abstract}

Palavras-chave: portos; comércio colonial; produtos coloniais.

Entre el Atlántico y la costa: confluencia de rutas mercantiles en un puerto periférico de la América portuguesa (Santos, 1808-1822)

\section{Resumen}

Este texto discute el carácter costero y atlántico de la actividad mercantil en el puerto de Santos entre 1808-1822 y las contradicciones resultantes de esta su doble condición, única en la costa sur de la América portuguesa. Esta discusión está fundamentada en datos obtenidos de los mapas de importación y exportación producidos por la aduana de Santos para la Real Junta de Comercio.

Palabras clave: puertos; comercio colonial; productos coloniales.

Between the Atlantic and the coast: confluence of trade routes in a peripheral port of Portuguese America (Santos, 1808-1822)

\section{Abstract}

This paper has approached the coastal and Atlantic characters of such commercial activity in the port of Santos between 1808 and 1822 and the contradictions arising of this double condition, which is unique in the Southern coast of Portuguese America. This discussion was based on data collected in importation and exportation maps produced by customs of Santos to the Royal Board of Trade.

Keywords: ports; colonial trade; colonial products.

Entre l'Atlantique et la côte: la confluence des routes commerciales dans un port périphérique de l'Amérique portugaise (Santos, 1808-1822)

\section{Résumé}

Cet article discute le caractère côtière et Atlantique de lactivité commerciale dans le port de Santos entre 1808-1822 et les contradictions qui proviennent de sa double condition, unique à la côte sud de l'Amérique portugaise. Cette discussion est basée sur des données recueillies dans les cartes d'importation et d'exportation produites par la douane de Santos pour la Real Junta de Comércio.

Mots-clés: les ports; le commerce colonial; les produits coloniaux. 
$\mathrm{N}$ Testa última década, a historiografia sobre o comércio no império português e na capitania de São Paulo, em especial, avançou de tal modo que deu condições para que o porto de Santos se tornasse alvo do interesse de pesquisas, as quais levassem à conceituação do peso e à natureza de sua atividade comercial na economia colonial.

A vila marítima de Santos foi um espaço periférico na costa sul em relação a outras cidades marítimas, como Rio de Janeiro ou Salvador, que se constituíam em efetivas praças mercantis do ponto de vista da complexa e variada acumulação de capitais e por concentrarem um restrito grupo de negociantes que formavam a elite econômica dominante da economia colonial. ${ }^{1}$

Contudo, nesta vila, existiu uma movimentação mercantil não desprezível, uma comunidade de negociantes residentes na cidade de São Paulo ou na própria região portuária, que atuavam nos mercados interno e externo, costeiro ou terrestre serra acima. ${ }^{2}$

Até então a historiografia associava a vila marítima de Santos ao comércio do sal ou do açúcar. ${ }^{3}$ Pesquisas mais recentes modificaram esta visão, mas ainda concluem que as atividades mercantis deste porto estavam restritas às demandas da praça do Rio de Janeiro. ${ }^{4} \mathrm{O}$ baixo número de entradas e saídas de embarcações do porto de Santos ainda é um problema para certos autores, que relacionam este dado a uma posição mercantil inferior ou de menor importância no âmbito mais geral do comércio no período colonial tardio. ${ }^{5}$

Nas páginas desta própria historiografia, contudo, há muitas menções, extraídas da própria documentação que fundamentam suas conclusões, a um ambiente mercantil de maior vitalidade e mais variado nas suas conexões com outros espaços na costa da América ou em Portugal.

Apesar da capitania de São Paulo fazer parte da hinterland do Rio de Janeiro, ${ }^{6}$ sua geografia costeira caracterizada pela existência de apenas um porto com saída direta para o atlântico, como era o caso de Santos e questões próprias do comércio no período colonial tardio, como o aumento e diversificação da demanda

\footnotetext{
'João Luís Fragoso, Homens de grossa aventura: acumulação e hierarquia na praça mercantil do Rio de Janeiro, 1790-1830, Rio de Janeiro, Civilização Brasileira, 1998, p. 40-49.

2João Luis Ribeiro Fragoso, et al., O antigo regime nos trópicos: a dinâmica imperial portuguesa (séculos XVIXVIII), Rio de Janeiro, Civilização Brasileira, 2001; João Luis Ribeiro Fragoso; Carla Maria Carvalho Almeida; Antonio Carlos Jucá Sampaio, Conquistadores e negociantes: história de elites no Antigo Regime nos trópicos. América Iusa, séculos XVI a XVIII, Rio de Janeiro, Civilização Brasileira, 2007; Helen Osório, O Império português no sul da América: estancieiros, lavradores e comerciantes, Porto Alegre, Editora da Universidade Federal do Rio Grande do Sul, 2007: Maria Lúcia Viveiros Araúio, Os caminhos das riquezas dos paulistanos na primeira metade do Oitocentos, São Paulo, Editoria HUCITEC/Fundação de Amparo à Pesquisa do Estado de São Paulo, 2006; Maria Aparecida Menezes Borrego, "Laços familiares e aspectos materiais da dinâmica mercantil na cidade de São Paulo (séculos XVIII e XIX), Anais do Museu Paulista, São Paulo, vol. 18, n. 1, 2010, p. 11-41; Denise A. Soares Moura, "Subsistemas de comércio costeiros e internalização de interesses na dissolução do Império colonial português, Santos (1788-1822)", Revista Brasileira de História, São Paulo, vol. 30, n. 59, 2010, p. 215-235.

${ }^{3}$ Maria Thereza Schorer Petrone, A lavoura canavieira em São Paulo, Expansão e declínio (1765-1888), São Paulo, Difusão Europeia do Livro, 1968.

${ }^{4}$ Renato Mattos, Política, administração e negócios na capitania de São Paulo e sua inserção nas relações mercantis do Império português (1788-1808), Dissertação (Mestrado) - Faculdade de Filosofia, Letras e Ciências Humanas da Universidade de São Paulo, São Paulo, 2009; Ana Paula Medici, Administrando conflitos: o exercício do poder e os interesses mercantis na capitania/provincia de São Paulo (1765-1822). Tese (Doutorado) Faculdade de Filosofia, Letras e Ciências Humanas da Universidade de São Paulo, São Paulo, 2010.

${ }^{5}$ Maximiliano M. Meinz, "Centro e periferias coloniais: o comércio do Rio de Janeiro com Santos e Rio Grande (1802-1818)". Revista de História, n. 154, São Paulo, 2006, p. 251-266.

${ }^{6}$ Conforme demonstrado por Larissa Brown para o período 1813-1819. Larissa Brown, Internal commerce in a colonial economy, Rio de Janeiro and its hinterland, 1790-1822. Tese (Doutorado), University of Virginia, Virginia, 1986
} 
por alimentos, imprimiram à atividade mercantil desta vila marítima um caráter complementador de demandas do mercado interno, tanto no próprio continente - pois as conexões comerciais ocorriam também com o Rio da Prata, como será visto - como externarmente. ${ }^{7}$

Na costa sul da América portuguesa, depois do Rio de Janeiro, apenas o porto de Santos tinha barra profunda, larga e apropriada para o atracamento de embarcações de grande porte, como navios. ${ }^{8}$ Em certas conjunturas, este porto foi alvo de políticas régias que contribuíram ainda mais para o seu fortalecimento como polo de um circuito mercantil costeiro. O governador Bernardo José de Lorena (17881797), por exemplo, pavimentou o difícil caminho de descida da serra, que ligava a cidade de São Paulo e, portanto, todo o interior da capitania ao litoral ${ }^{9}$ e adotou medidas para centralizar todo o comércio marítimo da capitania neste porto. Medidas estas que, embora abandonadas pelo governador posterior, Antonio Manuel de Melo e Castro e Mendonça (1797-1802), foram retomadas no seguinte de Antonio José da Franca e Horta (1802-1808).

Somente tal capacidade de uma área periférica situada na costa sul da América em desempenhar dois papéis na atividade mercantil do império - costeiro e atlântico - não a tornaria uma área interessante para pesquisa? Ao abrigar duas modalidades de comércio, a vila marítima de Santos não estaria sujeita ao fogo cruzado das concorrências de interesses, especialmente num momento em que o império lutava para se manter presente em seus domínios na América?

O texto que segue não irá conceituar grupos mercantis e, portanto, não aplicará explicitamente o conceito de rede ${ }^{10}$ ferramenta teórico-metodológica essencial que vem trazendo significativos avanços na temática do comércio no império. No entanto, acompanhando o movimento das mercadorias a partir do porto de Santos, por meio dos mapas de importação e exportação, foi possível construir uma teia de relações mercantis, que forneceu condições para qualificar a atividade mercantil de Santos no contexto maior dos impérios ibéricos na América.

Deste modo, o conceito de rede exerce alguma influência sobre este texto, mas ao invés de acompanhar a trajetória de indivíduos, a opção foi a de seguir a das mercadorias, que circularam por diversos espaços e também contribuíram para ligar várias regiões, vinculadas ou não ao império português.

Os dados dos mapas de importação e exportação de Santos, produzidos entre 1808 e 1821, embora não seriados, revelam que neste porto existia uma constelação de mercadorias coloniais que formava circuitos mercantis específicos e integrados a várias outras regiões na América meridional e em Portugal.

Estes circuitos mercantis analisados a partir de cada tipo de mercadoria, ao invés do número de embarcações, indicam que o Rio de Janeiro, até pelo menos 1818, não foi o monopolizador da aquisição de mercadorias coloniais provenientes do porto de Santos.

\footnotetext{
${ }_{7}^{7}$ osé Roberto do Amaral Lapa, O sistema colonial, São Paulo, Ática, 1991, p. 42 e p. 83-85.

${ }^{8}$ Caio Prado Jr., Evolução política do Brasil e outros estudos, São Paulo, Brasiliense, 1972, p. 105 e p. 117.

'Denise Mendes, A Calçada do Lorena: o caminho de tropeiros para o comércio do açúcar paulista, Dissertação (Mestrado) - Faculdade de Filosofia, Letras e Ciências Humanas da Universidade de São Paulo, São Paulo, 1994.

10 João Fragoso, Maria de Fátima Gouvêa (orgs.), Na trama das redes: política e negócios no Império português, séculos XVI-XVIII, Rio de Janeiro, Civilização Brasileira, 2011, p. 22-23.
} 
Deste modo, os dados aqui reunidos e analisados discordam das teses que restringem os interesses mercantis da vila de Santos aos do Rio de Janeiro. ${ }^{11}$ Entre o final do século XVIII e o início do XIX ocorreu uma ampliação e diversificação da demanda por alimentos e gêneros diversificados no continente e na Europa. Negociantes que atuavam nas cidades e vilas marítimas do Brasil podem ter procurado tirar proveito desta variação da demanda no mercado consumidor.

De fato, os dados levantados nos mapas de exportação dos gêneros coloniais do porto de Santos mostram que o número de embarcações destinadas ou oriundas dos portos portugueses atracadas em Santos foi infinitamente inferior às do Rio de Janeiro, como poderá ser visto nos dados que serão apresentados adiante. Mas isto seria suficiente para minimizar a importância das mercadorias oriundas de Santos nos portos portugueses e em certas conjunturas?

A partir de uma análise microscópica do interior das embarcações, ou seja, a partir do acompanhamento de cada um dos tipos de mercadorias embarcadas constatei que algumas delas eram enviadas para os portos portugueses em montantes bem superiores aos que seguiam para praça carioca.

Estes valores podem ser observados nas Tabelas 5 a 7 . Uma constatação como esta, contudo, não implica em restringir o peso e a natureza da atividade mercantil do porto de Santos ao mercado atlântico. ${ }^{12}$ Apenas indica que, na costa sul do continente, um porto periférico, como o de Santos, tinha uma atividade mercantil que oscilou entre o mercado externo e o interno, ocorrendo ainda uma variabilidade em suas movimentações internas. Desse modo, a praça mercantil do Rio de Janeiro não era o vínculo comercial predominante da vila marítima de Santos. A diversificação dos parceiros mercantis, nos mercados interno e externo, define a natureza da economia de tal vila.

Assim, para que fosse possível conceituar e problematizar o comércio de um porto periférico parecia mais interessante valorizar os tipos e as quantidades de cada mercadoria que enviavam para outros portos, pois o número de embarcações que se movimentavam em seu cais às vezes pode levar a conclusões enganosas.

Desde 1800 a demanda do mercado interno e externo por mercadorias coloniais mais diversificadas aumentou especialmente para algodão, arroz, café, couros e cacau, conforme demonstrou Valentim Alexandre. O açúcar, no entanto, ainda conservou altos patamares de exportação em meio a uma discreta recessão. ${ }^{13}$ Com isto, os portos periféricos, por serem zonas produtivas e terem acesso àquelas do interior do continente, tornaram-se locais alternativos e de complementação da demanda de mantimentos coloniais.

A conclusão desta pesquisa, portanto, é a de que portos periféricos e pequenos, como o de Santos, funcionavam como pontos de complementação da demanda por mercadorias coloniais existentes em portos maiores e cujo centro das operações mercantis era 0 atlântico.

\footnotetext{
"Renato Mattos, Política, administração e negócios na capitania de São Paulo e sua inserção nas relações mercantis do Império português (1788-1808), Dissertação (Mestrado) - Faculdade de Filosofia, Letras e Ciências Humanas da Universidade de São Paulo, São Paulo, 2009. Ana Paula Medici, Administrando conflitos: o exercício do poder e os interesses mercantis na capitania/província de São Paulo (1765-1822), Tese (Doutorado) Faculdade de Filosofia, Letras e Ciências Humanas da Universidade de São Paulo, São Paulo, 2010.

${ }^{12}$ Assim faz Pablo Oller Mont Serrat, Dilemas e conflitos na São Paulo restaurada: formação e consolidação da agricultura exportadora (1765-1802), Dissertação (Mestrado) - Faculdade de Filosofia, Letras e Ciências Humanas da Universidade de São Paulo, São Paulo, 2007.

${ }_{13}$ Valentim Alexandre, Os sentidos do Império: questão nacional e questão colonial na crise do Antigo Regime Português. Lisboa, Edições Afrontamento, 1993, p. 41.
} 
Os dados sistematizados e apresentados adiante indicam ainda que o porto de Santos teve papel atuante no abastecimento costeiro. Porém, esta atividade mercantil costeira exercida pelo porto de Santos foi complexa, caracterizada por vários circuitos de mantimentos, cujos volumes oscilavam: ora em maior número para $\mathrm{o}$ atlântico, ora em maior número para a costa sul do Brasil e mesmo para a região do Rio da Prata.

Toda a discussão que segue, portanto, qualifica a composição e as articulações do porto de Santos na costa centro-sul da América e no atlântico, especialmente em direção às cidades de Lisboa e Porto, exclusivamente do ponto de vista das exportações de mercadorias coloniais.

Na medida em que o comércio deste porto está sendo pensado em escala ampla, ou seja, a costa sul da América, o porto do Rio Grande, também um dos principais desta região costeira, é uma referência obrigatória, pois ele salienta e ajuda o leitor a entender a importância do porto de Santos como praticamente um centro exclusivo de comércio simultaneamente costeiro e atlântico, na costa sul e depois do Rio de Janeiro.

Rio Grande e Santos podem ser antagônicos no que diz respeito ao papel exportador que Santos também possui, ao contrário do Rio Grande, com uma fun-

\footnotetext{
Portos periféricos e pequenos, como o de Santos, funcionavam como pontos de complementação da demanda por mercadorias coloniais (...) cujo centro das operações mercantis era o Atlântico
}

ção especificamente de abastecimento interno por meio do comércio de couro, charque e trigo. ${ }^{14}$ Mas estes dois portos têm pontos em comum, tais como a mesma complexidade e a variabilidade de mercadorias exportadas na costa. O Rio Grande, conforme já foi demonstrado por pesquisas, tinha função especificamente de abastecimento interno, através do comércio do couro, charque e trigo.

\section{Santos: um porto periférico na américa como uma das rotas do comércio português}

Os dados da balança de comércio dos portos das cidades do Porto e Lisboa sistematizados e analisados por Valentim Alexandre contribuem para fundamentar uma das conclusões deste texto: a de que o porto de Santos foi uma rota complementar das demandas por produtos coloniais diversificados existente nestes dois portos portugueses. ${ }^{15}$

\footnotetext{
${ }^{14}$ Helen Osório, O Império português no sul da América: estancieiros, lavradores e comerciantes, Porto Alegre, Editora da Universidade Federal do Rio Grande do Sul, 2007.

${ }^{15}$ Valentim Alexandre, Os sentidos do Império: questão nacional e questão colonial na crise do Antigo Regime Português. Lisboa, Edições Afrontamento, 1993.
} 
Por meio de tal documentação, o autor demonstrou o surgimento de um novo modelo das exportações do comércio do império a partir de 1800, que é explicável pela relativa recessão do açúcar e do tabaco, pelo crescimento da demanda pelo algodão e acréscimo do valor absoluto da exportação de produtos secundários como couros, arroz, café e cacau. ${ }^{16}$

Desde 1751 fora instalada no Rio de Janeiro a Mesa de Inspeção, subordinada à Junta de Comércio em Lisboa e responsável por controlar a qualidade e o comércio do açúcar exportado por este porto. Este produto, portanto, tinha de passar pelo porto do Rio de Janeiro, onde encontraria os mecanismos burocráticos de controle de sua qualidade e tributação.

Mas algum açúcar seguia direto de Santos, um porto periférico e que, apesar de dispor de uma alfândega, possuía uma estrutura burocrática mais frouxa, tendo em vista a tardia intensificação de sua atividade mercantil. ${ }^{17}$ De lá, saiam principalmente mantimentos coloniais. ${ }^{18}$

A atividade mercantil atlântica de Santos adquiriu condições para se desenvolver a partir de 1788, com o governo de Bernardo José de Lorena, como foi mencionado acima. Outros portos do sul, como Rio Grande e Santa Catarina, como demonstra a Tabela 1, não tiveram a mesma regularidade que Santos, do ponto de vista do comércio direto com Lisboa.

Algumas teses comprovaram como a expansão do mercado interno no período colonial tardio implicou no fortalecimento dos vínculos mercantis entre os portos da costa sul e o do Rio de Janeiro. ${ }^{19} \mathrm{~A}$ elite mercantil estabelecida no porto carioca também estava relacionada aos negócios do mercado interno de abastecimento, ${ }^{20}$ e os portos do Sul foram sua fonte de acesso às mercadorias coloniais que circulariam em tal mercado.

Deve-se considerar também a força de influência das características geográficas $^{21}$ dos portos do Sul para o estabelecimento deste tipo de vinculação mercantil. Santos era o único na costa sul com barragem profunda e adequada para navios.

Comparando a movimentação atlântica do porto de Santos com às do Rio Grande e Santa Catarina, percebe-se, de fato, que Santos recebia navios oriundos de Lisboa com regularidade. Portanto, neste porto em especial, da capitania de São Paulo, ocorreu também, embora em nível secundário, porém significativo, o desenvolvimento da atividade mercantil atlântica. Os produtos coloniais do porto de Santos estiveram sob a competição de dois circuitos mercantis: o do atlântico e o do mercado interno de abastecimento (Tabela 1).

\footnotetext{
${ }^{16}$ Valentim Alexandre, Os sentidos do Império: questão nacional e questão colonial na crise do Antigo Regime Português. Lisboa, Edições Afrontamento, 1993, p. 41-44.

${ }^{17}$ Cf. Denise A. Soares Moura, "Subsistemas de comércio costeiros e internalização de interesses na dissolução do Império colonial português, Santos (1788-1822)", Revista Brasileira de História, São Paulo, vol. 30, n. 59, 2010, p. $215-235$. ${ }^{18}$ Estou usando esta expressão por ser extremamente comum na documentação dos séculos 18 e 19 e referirse a gêneros da alimentação cotidiana, tanto secos (farinha, milho, feijão e café) como molhados (banha, toucinho, queijo, aguardente e doce).

${ }^{19}$ Helen Osório, O Império português no sul da América: estancieiros, lavradores e comerciantes, Porto Alegre, Editora da Universidade Federal do Rio Grande do Sul, 2007. Rudolph W. Bauss, Rio de Janeiro: the rise of late colonial Brazil's emporium, 1777-1808, New Orleans, PhD dissertation, Tulane University, 1977; Larissa B. Brown, Internal commerce in a colonial economy, Rio de Janeiro and its hinterland, 1790-1822, Tese (Doutorado), University of Virginia, Virginia, 1986, p. 425-434

${ }^{20}$ João Luís Fragoso, Homens de grossa aventura: acumulação e hierarquia na praça mercantil do Rio de Janeiro, 1790-1830, Rio de Janeiro, Civilização Brasileira, 1998.

${ }^{2}$ Sobre os privilégios geográficos Cf. Pierre Chaunu, Expansão europeia do século XIII ao XV, São Paulo, Pioneira, 1978, p. 80-81.
} 
Tabela 1 - Lista das equipagens de navios que saíram de Lisboa e seguiram para portos o Sul da América portuguesa. Dados levantados no Fundo Junta de Comércio. Série "Navegação, matrícula das equipagens de navios". ANTT, Maço 34, cx. 114; maço 35, cxs. 116, 117, 118, 119; maço 379, cx. 757 e série “Relações de entradas e saídas dos navios do porto de Lisboa." Maço 310, cx. 620.

\begin{tabular}{|c|c|c|c|}
\hline & Santos & Rio Grande & Ilha de Santa Catarina \\
\hline 1788 & $\begin{array}{l}\text { Nossa Senhora do Carmo e Santo } \\
\text { Antonio, Francisco de Abreu, com sal e } \\
\text { fazendas }\end{array}$ & & \\
\hline 1789 & $\begin{array}{l}\text { Navio Nossa Senhora do Belém, e São } \\
\text { João Batista, segue para Santos e Rio } \\
\text { de Janeiro }\end{array}$ & & \\
\hline 1791 & $\begin{array}{l}\text { Bergantim Nossa Senhora do Carmo e } \\
\text { Bonfim, segue direto }\end{array}$ & & \\
\hline 1792 & $\begin{array}{l}\text { Curveta Nossa Senhora da Conceição } \\
\text { e Santa Anna, segue para Santos e } \\
\text { Rio Grande }\end{array}$ & & \\
\hline 1793 & $\begin{array}{l}\text { Nossa Senhora da Piedade e Flor da } \\
\text { América, Antonio Luiz Pereira, para Santos } \\
\text { e outros portos, com vários gêneros }\end{array}$ & & \\
\hline 1796 & $\begin{array}{l}\text { Bergantim Monte do Carmo e Leão } \\
\text { "segue viagem para Santos capitânia } \\
\text { de São Paulo" }\end{array}$ & & \\
\hline 1798 & $\begin{array}{l}\text { Navio Margarida "que segue viagem } \\
\text { para Santos e Rio de Janeiro" }\end{array}$ & $\begin{array}{l}\text { Bergantim N. S. do Monte } \\
\text { do Carmo, Santo Antonio e } \\
\text { Almas, "que segue viagem } \\
\text { no presente comboio/ } \\
\text { Brigue Animo Grande" }\end{array}$ & \\
\hline 1799 & Corveta Santo Antonio Boa Ventura & & \\
\hline 1801 & $\begin{array}{l}\text { Bergantim Monte do Carmo e Sião/ } \\
\text { Corveta Senhor dos Passos e Santo } \\
\text { Antonio }\end{array}$ & & \\
\hline 1802 & $\begin{array}{l}\text { Navio Pensamento Ligeiro/Navio São } \\
\text { Francisco Xavier, "que segue viagem } \\
\text { para Bengala com escala pela Ilha da } \\
\text { Madeira e Rio de Janeiro a Santos" }\end{array}$ & $\begin{array}{l}\text { Bergantim Suzana, } \\
\text { com escala pelo Rio de } \\
\text { Janeiro }\end{array}$ & $\begin{array}{l}\text { Galera Ártico. Tem como } \\
\text { marinheiros um de } \\
\text { Santa Catarina, um de } \\
\text { São Francisco do Sul, } \\
\text { com } 13 \text { anos }\end{array}$ \\
\hline 1803 & $\begin{array}{l}\text { Navio Pensamento Ligeiro, com escala } \\
\text { em Pernambuco e Alegria Constante, } \\
\text { que segue viagem direto, partindo de } \\
\text { Lisboa e sem escala }\end{array}$ & & \\
\hline 1805 & $\begin{array}{l}\text { Navio Conceição Minerva, partindo de } \\
\text { Lisboa e sem escala }\end{array}$ & $\begin{array}{l}\text { Galera Providencia, com } \\
\text { escala pelo Rio de Janeiro e } \\
\text { Pataxó }\end{array}$ & \\
\hline 1806 & & $\begin{array}{l}\text { Bergantin Rio Mondogo } \\
\text { que segue direito }\end{array}$ & \\
\hline 1807 & $\begin{array}{l}\text { Navio Indiano, com escala no Rio de } \\
\text { Janeiro }\end{array}$ & $\begin{array}{l}\text { Bergantim Lebre, segue } \\
\text { direto sem escala }\end{array}$ & \\
\hline
\end{tabular}


Essa dupla capacidade não teria feito do porto de Santos, diferentemente do Rio Grande, uma área na qual a atividade mercantil poderia ser mais autônoma e tirar mais proveito das conjunturas econômicas? Os próximos dados sugerem que sim.

A abertura dos portos em 1808 e o fim da era de governadores da capitania que atuaram no sentido de fortalecer a exclusividade do porto de Santos no comércio colonial tardio, como foram os casos de Bernardo José de Lorena e Franca e Horta, não impactaram negativamente suas atividades mercantis.

A vila de Santos, por outro lado, foi uma fornecedora de açúcar diretamente para Lisboa, passando ao largo, portanto, da própria Mesa de Inspeção, e também uma importante fornecedora de "outros gêneros" que serão chamados de consumo cotidiano, tais como: a aguardente, $\mathrm{o}$ arroz, o couro, sendo que este último não vinha do Rio Grande, mas do circuito platino, ou seja, os gêneros não perecíveis.

A Tabela 2 indica a movimentação das embarcações portuguesas no porto de Santos, ou seja, aquelas que saíram levando mercadorias coloniais em comparação com às destinadas ao Rio de Janeiro.

Ao longo dos 11 anos possíveis de serem documentados, notou-se que as saídas de Santos para o Rio de Janeiro foram infinitamente superiores, totalizando 386, e

$$
\begin{aligned}
& \text { As viagens das embarcações entre Santos-Rio de } \\
& \text { Janeiro foram de fato superiores em relação aos } \\
& \text { portos do reino. Mas isto não significa que a praça } \\
& \text { carioca foi a maior compradora de Santos }
\end{aligned}
$$

as dirigidas aos portos portugueses somaram 42. Essa constatação pode animar a ideia de que a economia da vila de Santos era satélite da praça do Rio de Janeiro.

Lisboa e Porto adquiriram volumes superiores de mercadorias da cidade marítima de Santos em relação ao Rio de Janeiro, como pode ser constatado na análise individualizada de cada tipo de produto negociado. As viagens das embarcações entre Santos-Rio de Janeiro foram de fato superiores em relação aos portos do reino. Mas isto não significa que a praça carioca foi a maior compradora de Santos. As condições favoráveis deste porto para o comércio atlântico, diferente de qualquer outro na costa sul do Brasil, podem ser um dos fatores explicativos para esta questão, ou seja, este era um porto que podia diversificar seus espaços de negociação, vinculando-se mais ou menos a um ou outro de acordo com as circunstâncias da economia.

A Tabela 2 também indica que havia ainda um circuito Santos-portos portugueses, cuja centralidade era exercida pela cidade do Porto e não por Lisboa. Lisboa, segundo Valentim Alexandre, era o principal entreposto do comércio colonial, tanto na redistribuição dos produtos do Brasil na Europa, como na re-exportação de 
Tabela 2. Número de embarcações que saíram do porto de Santos e seus destinos. Dados levantados em mapas de importação e exportação do porto de Santos, período de 1808 a 1821. Fundo Real Junta de Comércio, caixa 448, pacote 1, Arquivo Nacional, Rio de Janeiro.

\begin{tabular}{lcccccccccccc} 
& 1808 & 1810 & 1811 & 1812 & 1815 & 1816 & 1817 & 1818 & 1819 & 1820 & 1821 & Total \\
Lisboa & 1 & & & 1 & 3 & 2 & 3 & 1 & 2 & 2 & 1 & 16 \\
\hline $\begin{array}{l}\text { Porto } \\
\text { Rio de } \\
\text { Janeiro }\end{array}$ & 13 & 2 & 2 & 4 & 2 & 3 & 1 & 6 & 2 & 2 & 2 & 26 \\
\hline
\end{tabular}

mercadorias europeias no Brasil. A cidade do Porto tinha uma carta de clientes de produtos coloniais bastante inferior, como concluído pelo mesmo autor. ${ }^{22}$

Em vista disto, considera-se que zonas mercantis periféricas no Brasil, como Santos, podem ter sido uma rota alternativa de mercadorias coloniais dirigidas aos portos periféricos portugueses. A historiografia já demonstrou a força da influência, capitalização e inserção de negociantes de Lisboa na praça carioca. ${ }^{23}$

Os portos portugueses periféricos podem ter buscado as vilas marítimas da costa do Brasil como uma rota alternativa de acesso a mercadorias coloniais que seriam usadas em seu abastecimento interno e não propriamente para re-exportação, visto que tais portos não tinham este papel como significativo ou principal, já que este era desempenhado por Lisboa.

Na capitania de São Paulo, durante o governo de Franca e Horta, surgiu a intenção de ligar comercialmente o porto de Santos com a cidade do Porto. Em 1803, durante o governo de Franca e Horta, na capitania de São Paulo, saiu a primeira embarcação do porto de Santos com destino à cidade do Porto. Não ocasião, o objetivo foi o de estabelecer linhas de comércio entre a região e a Companhia das Vinhas do Alto Douro. ${ }^{24}$

Mesmo com o fim de seu governo, em 1811, esta conexão mercantil SantosPorto permaneceu, o que sugere que este circuito mercantil específico não esteve preso à ação circunstancial de um funcionário do Reino, mas respondia às demandas por mercadorias coloniais diversificadas na época e pela lógica dos portos periféricos em Portugal procurarem estabelecer relações mercantis com portos periféricos no Brasil. Portos periféricos tinham estrutura fiscal e de funcionários mais frágil ${ }^{25} \mathrm{o}$ que certamente os tornava mais atraentes para negociações.

Importante também é destacar que o Porto, em especial, absorveu uma quantidade de certas mercadorias - mantimentos — bem superior às da praça do Rio de Janeiro, mesmo tendo enviado para Santos um número inferior de navios, como será futuramente analisado. Para essas mercadorias, em especial, o volume dos

\footnotetext{
${ }^{22}$ Valentim Alexandre, Os sentidos do Império: questão nacional e questão colonial na crise do Antigo Regime Português. Lisboa, Edições Afrontamento, 1993, p. 57-58.

${ }^{23}$ João Fragoso, Manolo Florentino, 0 arcaísmo como projeto: mercado atlântico, sociedade agrária e elite mercantil em uma economia colonial tardia, c. 1790-c.1840, 4 ed., Rio de Janeiro, Civilização Brasileira, 2001; Jorge Miguel de Melo Viana Pedreira, Os homens de negócio da praça de Lisboa de Pombal ao vintismo (17551822). Diferenciação, reprodução e identificação de um grupo social, Lisboa, Universidade Nova de Lisboa, 1995. ${ }^{24}$ Ana Paula Medici, Administrando conflitos: o exercício do poder e os interesses mercantis na capitania/ província de São Paulo (1765-1822), Tese (Doutorado) - Faculdade de Filosofia, Letras e Ciências Humanas da Universidade de São Paulo, São Paulo, 2010. p. 156.

${ }^{25}$ Denise A. Soares Moura, "Subsistemas de comércio costeiros e internalização de interesses na dissolução do Império colonial português, Santos (1788-1822)", Revista Brasileira de História, São Paulo, vol. 30, n. 59, 2010, p. 215-235.
} 
negócios foi maior, visto que os preços dos gêneros eram os mesmos, independentemente do local em que eram vendidos.

O Rio de Janeiro era comprovadamente um importante parceiro de Santos na costa, como demonstra a Tabela 2. Porém não monopolizava seus negócios, pois, como observado na Tabela 3, os destinos portuários das saídas de Santos eram muito diversificados.

A expressão do governador Bernardo José de Lorena muito conhecida dos estudiosos da história da capitania de São Paulo, ${ }^{26}$ ou seja, que os negociantes de Santos agiam como caixeiros dos do Rio de Janeiro, portanto, perde sentido diante da movimentação portuária apresentada pela Tabela 3. A realidade mercantil do Porto de Santos era bem mais variada, independente e contemplava seguramente a rota do Reino e, principalmente, do Porto.

Na comparação das Tabelas 2 e 3, contudo, há uma inflexão deste movimento, especialmente a partir de 1817. Portanto, o Rio de Janeiro abriu uma enorme diferença em relação aos outros portos no que diz respeito à absorção das embarcações provenientes do porto de Santos.

Se Santos passou a vender menos para os portos menores nas costas norte e sul

$$
\begin{gathered}
\text { A expressão do governador Bernardo José de Lorena, } \\
\text { que os negociantes de Santos agiam como caixeiros } \\
\text { dos do Rio de Janeiro, perde sentido diante da } \\
\text { movimentação portuária. }
\end{gathered}
$$

da capitania de São Paulo ou para o Rio Grande e às províncias da Bacia do Prata, algumas explicações podem ser apontadas. Para o caso das vilas do Norte da capitania, o intervalo entre o declínio da produção açucareira e a consolidação da economia do café pode ter estimulado a produção interna dos alimentos de regiões como São Sebastião e Ubatuba, o que implicava na diminuição das aquisições de mantimentos em portos como Santos. ${ }^{27}$

O Rio Grande foi em grande medida abastecido em alimentos pelo Rio de Janeiro e os negociantes deste porto estavam inclusive geneticamente ligados aos da praça carioca. ${ }^{28}$

Se antes de 1818 o extremo sul viveu uma conjuntura de maiores intercâmbios mercantis com o porto de Santos, conforme percebido nos números da Tabela 3, isto pode ser explicado pelo grande produção da região em produtos específicos com alta demanda no consumo interno (charque e trigo) e em negócios externos (couros) do Rio de Janeiro.

\footnotetext{
26“Tem sido necessárias muitas providências para evitar a saída dos efeitos de comércio com a Europa para o Rio de Janeiro (havendo aqui navios a carga de bom conceito) pelo costume, em que estavam os negociantes de São Paulo, desmerecerem menos este nome, do que o de caixeiros dos do Rio".

Ofício do governador Bernardo José de Lorena para S.M em 28/06/1797. Documentos interessantes para a história e costumes de São Paulo, vol. 45, p. 208.

${ }^{27}$ Ramón Garcia Férnandez, "Concentração da riqueza e crescimento econômico no litoral norte paulista (1778-1836)", Estudos Sociedade e Agricultura, 1998, p. 165-189.

${ }^{28}$ Helen Osório, O Império português no sul da América: estancieiros, lavradores e comerciantes, Porto Alegre, Editora da Universidade Federal do Rio Grande do Sul, 2007, p. 219.
} 
Tabela 3. Número de embarcações que saíram do porto de Santos e seus destinos. Dados levantados em mapas de importação e exportação do porto de Santos, período de 1808 a 1821 . Fundo Real Junta de Comércio, caixa 448, pacote 1, Arquivo Nacional, Rio de Janeiro.

$\begin{array}{lllllllllllll}1808 & 1809 & 1810 & 1811 & 1812 & 1814 & 1815 & 1816 & 1817 & 1818 & 1819 & 1820 & 1821\end{array}$

\begin{tabular}{|c|c|c|c|c|c|c|c|c|c|c|c|c|c|}
\hline Cabo Verde & & & & & 1 & & & & & & 1 & & \\
\hline Ilha 3a. & & & & & & & & & & & 1 & & \\
\hline $\begin{array}{l}\text { Illha da } \\
\text { Madeira }\end{array}$ & 1 & & 1 & 2 & & & & & & & & & \\
\hline Maranhão & & & & & & & & & & 2 & 2 & 1 & \\
\hline Boa Vista & & & 1 & & & & & & & & & & \\
\hline São Mateus & & & & & & & & & & & 1 & 2 & \\
\hline Pernambuco & 1 & & 3 & 3 & 2 & 2 & 4 & 13 & 13 & 5 & 8 & 7 & 7 \\
\hline Porto Seguro & & & & 1 & & & & & & & & & \\
\hline Bahia & 2 & 2 & 1 & 4 & 1 & & 3 & 2 & 8 & 7 & 5 & 4 & 8 \\
\hline Paraty & & & & 1 & 1 & & & & & & 1 & 1 & \\
\hline Ilha Grande & & & 1 & & & & 1 & & & & & 2 & \\
\hline Caravellas & 2 & & & & & & & & & & 2 & & \\
\hline Vila Bella & & & 1 & 1 & & & 2 & & & 3 & 1 & & \\
\hline Ubatuba & & & & 1 & & & & 1 & & & & & \\
\hline $\begin{array}{l}\text { São } \\
\text { Sebastião }\end{array}$ & 27 & & 5 & 10 & 4 & & 4 & 5 & 4 & & 3 & 3 & 3 \\
\hline Iguape & 10 & & 9 & 6 & 7 & & 6 & 11 & 4 & 4 & 4 & 9 & 11 \\
\hline Cananeia & 5 & & 1 & 2 & & & & & & & & & 3 \\
\hline Guaratuba & & & & 1 & & & & & & & & & 1 \\
\hline Paranaguá & 15 & & 6 & 4 & 7 & & 7 & 9 & 6 & 5 & 6 & 3 & 5 \\
\hline $\begin{array}{l}\text { Rio de São } \\
\text { Francisco }\end{array}$ & & & 3 & 2 & 1 & & 2 & & 3 & 2 & 5 & 1 & 1 \\
\hline $\begin{array}{l}\text { Illha de Santa } \\
\text { Catarina }\end{array}$ & 2 & & 2 & 1 & 1 & & 5 & 3 & 1 & 2 & 9 & 11 & 11 \\
\hline Laguna & & & 1 & 1 & & & 2 & & 1 & & 3 & 1 & 2 \\
\hline Rio Grande & 24 & & 10 & 17 & 10 & & 11 & 11 & 9 & 1 & 6 & 5 & 11 \\
\hline Porto Alegre & & & 1 & & 5 & & 3 & 1 & & 1 & 2 & 1 & 1 \\
\hline Montevidéu & & & 1 & 11 & 6 & & & & 2 & 1 & 2 & 5 & 3 \\
\hline Buenos Aires & & & 6 & 2 & 2 & & 10 & 6 & & 1 & & 5 & 2 \\
\hline Moçambique & 1 & & & & & & & & & & & & 1 \\
\hline
\end{tabular}

Apesar de Helén Osório ter constatado que a estrutura produtiva do Rio Grande era semelhante àquela identificada por Juan Carlos Garavaglia na região do Rio da Prata e protagonizada mais por lavradores de alimentos do que por criadores, certamente esta produção não completava a demanda local. ${ }^{29}$ Caso contrário, não te-

\footnotetext{
${ }^{29}$ Helen Osório, O Império português no sul da América: estancieiros, lavradores e comerciantes, Porto Alegre, Editora da Universidade Federal do Rio Grande do Sul, 2007, p. 83; Juan Carlos Garavaglia, Pastores e labradores de Buenos Aires: una historia agraria de la campana bonaerense 1700-1830, Buenos Aires, Ediciones de la Flor, 1999
} 
ria ocorrido o intercâmbio com o porto de Santos mostrado na Tabela 3 e antes de 1811.

Do mesmo modo, o rio da Prata, apesar de ser uma área produtiva de alimentos, viveu conjunturas de comércio com o porto de Santos. A atividade mercantil deste porto, portanto, no período colonial tardio, teve uma natureza complementadora de demandas internas e externas, em conjunturas específicas.

Tal condição o encaixa nas percepções de Sérgio Buarque de Holanda, o qual, sem dados estatísticos, intuiu que na capitania de São Paulo esbateram-se forças expansivas e de retração até o advento da cafeicultura, quando de fato o porto de Santos se tornou cabeça das exportações no centro-sul. ${ }^{30}$

\section{Mantimentos coloniais em circuitos mercantis}

Malgrado as pressões de produtores da costa e negociantes de outras vilas marítimas da capitania ${ }^{31}$ capazes apenas, inclusive por razões naturais, de praticar o comércio de cabotagem, os negócios do porto de Santos com os do reino mantiveram regularidade ao longo das duas primeiras décadas do século 19, como visto na Tabela 1.

Neste sentido, devido ao fato de agregar duas modalidades mercantis, atlântica e costeira, na costa sul, o porto de Santos pode ser considerado uma área da América portuguesa mais complexa e com relações mais contraditórias do que as que ocorriam no porto do Rio de Grande, que é uma zona portuária estritamente direcionada ao mercado interno e fortemente ligada ao Rio de Janeiro.

A possibilidade de agregar as duas modalidades mercantis - mercado atlântico e comércio de cabotagem -, praticando-as com grande margem de liberdade e conforme as conjunturas, não explicaria a inserção segura que grupos políticos de São Paulo, como a família Andrada, teve na nova conformação política de 1822?

O deputado Antonio Carlos de Andrada e Silva, ${ }^{32}$ nas cortes constituintes, defendeu a racionalização da navegação costeira, por meio da alta tributação. Essa não seria uma maneira de colocar-se como porta-voz de negociantes envolvidos com este tipo de atividade mercantil nesta área específica do império ?33

O conflito doméstico entre portugueses do reino recém-chegados e aqueles nascidos no reino ou na América, vislumbrado por Maria Odila Leite, ${ }^{34}$ não poderia ser associado, na vila de Santos, à concorrência entre a defesa da livre atuação nos

\footnotetext{
30Sérgio Buarque de Holanda, História Geral da Civilização Brasileira, 6 ed., Rio de Janeiro, Bertrand Brasil, tomo 2, vol. 2, 1995, p. 416-472.

${ }^{31}$ Renato Mattos, Política, administração e negócios na capitania de São Paulo e sua inserção nas relações mercantis do Império português (1788-1808), Dissertação (Mestrado) - Faculdade de Filosofia, Letras e Ciências Humanas da Universidade de São Paulo, São Paulo, 2009. p. 73; 84.

${ }^{32}$ Irmão de José Bonifácio de Andrada e Silva. A família Andrada era originária da vila marítima de Santos. O pai, Bonifácio José de Andrada e Silva, fora negociante na mesma vila. Há muita informação dispersa nas documentações administrativa municipal e régia sobre sua atuação. Ora aparece contribuindo com recursos para a formação de uma companhia de comércio em direitura com Lisboa, em 1768, ora envolvido na condução de farinhas para o Sul. Este é um negociante que merece investigação detida. Quanto aos filhos, fizeram parte da geração de ilustrados participativa da administração pública no período colonial tardio. Antonio Carlos foi juiz de fora da vila de Santos e José Bonifácio foi membro do governo provisório instalado na cidade de São Paulo, em 1821. Ambos são fartamente trados na historiografia, porém merecem biografias que se detenham sobre sua inserção política tanto na de Santos, como na de São Paulo. Cf. Souza, Otávio Tarquínio de Souza, José Bonifácio, Belo Horizonte, Itatiaia, 1988.

${ }^{33}$ Denise A. Soares Moura, "Subsistemas de comércio costeiros e internalização de interesses na dissolução do Império colonial português, Santos (1788-1822)", Revista Brasileira de História, São Paulo, vol. 30, n. 59, 2010, p. $215-235$. ${ }^{34}$ Maria Odila Leite da Silva Dias, “A interiorização da metrópole (1808-1853)". In: Carlos Guilherme Mota, 1822: dimensões, 2 ed, São Paulo, Perspectiva, 1986, p. 160-186.
} 
circuitos mercantis atlânticos e costeiros e as relações mercantis mais exclusivistas com o Reino, amparadas pelas políticas de governadores como Bernardo José de Lorena ou Franca e Horta?

Sem dúvida que os negócios com os portos do Reino eram vantajosos e foram muito além de 1808. Em certas conjunturas, a ação dos governadores que queriam fortalecer os negócios de São Paulo com o reino foi uma boa oportunidade. No entanto, o comércio não funciona por obrigações, e especialmente após a oficialização da liberdade mercantil nenhuma política restritiva, monopolista conseguiria se firmar.

Até 1822 Santos foi umas das rotas de confluência da atividade mercantil de Portugal. Este processo, contudo, recebeu vários incentivos no século XVIII, porém pulverizados em ações oficiais iniciadas em 1768, no governo de D. Luis de Sousa Botelho Mourão. Este governador tentou formar uma companhia de comércio que ligava Santos diretamente a Lisboa. Em 1798 novo incentivo foi dado neste sentido. ${ }^{35}$ O período de $1808-1822$, que pode ser mais consistentemente documentado, representa na realidade a continuidade de um processo inaugurado no período anterior. O mapa de mercadorias que participava desta atividade mercantil era conforme ao que pode ser visto na Tabela 4 .

O açúcar era enviado para os três portos principais: Porto, Lisboa e Rio de

\section{Os negócios do porto de Santos com os portugueses mantiveram-se firmes até a independência}

Janeiro. Em seguida, vinham importantes gêneros da alimentação e com alta demanda interna, como arroz, café, banha, toucinho, aguardente e o couro em cabelo. $\mathrm{O}$ último era um gênero fortemente controlado pelo circuito Rio Grande-Rio de Janeiro, mas que Santos conseguia ocupar certo espaço, certamente em virtude da alta demanda das nações com forte atividade mercantil oceânica de produtos primários, pois esta matéria era utilizada para enfardamento de mercadorias para exportação.

A cidade do Porto, como será observado adiante, era a maior compradora de couro em cabelo de Santos. Como Lisboa estava bem consolidada neste circuito controlado pelo Rio de Janeiro-Rio Grande, Santos aparecia como uma rota alternativa a fim de que o Porto também tivesse acesso a este produto de alta demanda.

\section{Portos portugueses na rota dos mantimentos da Vila de Santos}

A conclusão mais significativa que pode ser tirada dos dados reunidos nas Tabelas 1 a 4 é a das quantidades superiores de certas mercadorias que Santos vendia para as cidades marítimas de Porto e Lisboa, as quais, inclusive, eram superiores às vendidas por Santos na praça mercantil do Rio de Janeiro.

\footnotetext{
${ }^{35}$ Esta afirmação inspira-se em documento localizado no Arquivo do Estado de São Paulo, Mapa da exportação dos produtos da paróquia da vila de Santos em 1798. Alfândega - almoxarifado 1722-1822, Santos, C00227, doc. 1-25-2
} 
Os negócios do porto de Santos com os portugueses, portanto, mantiveram-se firmes até a independência, o que indica que em tal vila marítima atuavam negociantes de duas frentes: mercado interno de abastecimento e externo.

Tabela 4. Produtos enviados pelo porto de Santos aos àqueles de Porto, Lisboa e Rio de Janeiro. Dados levantados em mapas de importação e exportação do porto de santos, período entre 1810 a 1821. Fundo Real Junta de Comércio, caixa 448, pacote 1, Arquivo Nacional, Rio de Janeiro.

\begin{tabular}{|c|c|c|c|}
\hline & Porto & Lisboa & Rio de Janeiro \\
\hline 1810 & $\begin{array}{l}\text { Açúcar branco, açúcar } \\
\text { mascavo, arroz, couros } \\
\text { em cabelo, banha, } \\
\text { aguardente }\end{array}$ & - & $\begin{array}{l}\text { Açúcar branco, açúcar } \\
\text { mascavo, arroz }\end{array}$ \\
\hline 1814 & $\begin{array}{l}\text { Açúcar branco, açúcar } \\
\text { mascavo, arroz, pipas de } \\
\text { aguardente, café, anil, } \\
\text { banhas de porco, toicinho, } \\
\text { doce, couros em cabelo, } \\
\text { sola, pontas de boi }\end{array}$ & $\begin{array}{l}\text { Aguardente de cana, } \\
\text { café, arroz, toicinho, } \\
\text { banha de porco }\end{array}$ & $\begin{array}{l}\text { Açúcar branco, açúcar } \\
\text { mascavo, arroz, } \\
\text { aguardente, café, banha } \\
\text { de porco, toicinho, } \\
\text { couros em cabelo }\end{array}$ \\
\hline 1815 & $\begin{array}{l}\text { Açúcar branco, açúcar } \\
\text { mascavo, arroz, banha, } \\
\text { café, goma, couros em } \\
\text { cabelo, aguardente }\end{array}$ & $\begin{array}{l}\text { Açúcar branco, açúcar } \\
\text { mascavo, arroz, café, } \\
\text { couros em cabelo, } \\
\text { meios de sola Taboado }\end{array}$ & $\begin{array}{l}\text { Açúcar branco, açúcar } \\
\text { mascavo, arroz, banha, } \\
\text { café }\end{array}$ \\
\hline 1816 & $\begin{array}{l}\text { Açúcar branco, açúcar } \\
\text { mascavo, arroz, café, } \\
\text { banha, aguardente do } \\
\text { Brasil, couros em cabelo, } \\
\text { pontas de boi }\end{array}$ & $\begin{array}{l}\text { Açúcar branco, açúcar } \\
\text { mascavo, arroz, café, } \\
\text { banha, sebo, couros em } \\
\text { cabelo, aguardente }\end{array}$ & $\begin{array}{l}\text { Açúcar branco, açúcar } \\
\text { mascavo, banha, café, } \\
\text { arroz }\end{array}$ \\
\hline 1817 & $\begin{array}{l}\text { Açúcar branco, açúcar } \\
\text { mascavo, arroz, banha, } \\
\text { café, couros em cabelo, } \\
\text { pontas de boi, tabuado }\end{array}$ & $\begin{array}{l}\text { Açúcar branco, açúcar } \\
\text { mascavo, arroz, couro } \\
\text { em cabelo, banha }\end{array}$ & $\begin{array}{l}\text { Açúcar branco, açúcar } \\
\text { mascavo, arroz, banha, } \\
\text { café }\end{array}$ \\
\hline 1818 & $\begin{array}{l}\text { Açúcar branco, açúcar } \\
\text { mascavo, arroz, banha, } \\
\text { toucinho, café, couro } \\
\text { em cabelo, farinha, } \\
\text { aguardente, ponta de boi }\end{array}$ & $\begin{array}{l}\text { Açúcar branco, açúcar } \\
\text { mascavo, couros em } \\
\text { cabelo, arroz, café, } \\
\text { aguardente }\end{array}$ & $\begin{array}{l}\text { Açúcar branco, açúcar } \\
\text { mascavo, arroz, café, } \\
\text { banha, toucinho, couros } \\
\text { em cabelo, aguardente }\end{array}$ \\
\hline 1819 & $\begin{array}{l}\text { Açúcar branco, açúcar } \\
\text { mascavo, banha, café, } \\
\text { goma, aguardente, arroz, } \\
\text { algodão }\end{array}$ & $\begin{array}{l}\text { Açúcar branco, açúcar } \\
\text { mascavo, banha, café, } \\
\text { goma, aguardente, arroz, } \\
\text { algodão, couro em cabelo }\end{array}$ & $\begin{array}{l}\text { Açúcar branco, açúcar } \\
\text { mascavo, banha, café, } \\
\text { arroz, couros em cabelo, } \\
\text { algodão em rama }\end{array}$ \\
\hline 1820 & $\begin{array}{l}\text { Açúcar branco, açúcar } \\
\text { mascavo, banha, couros } \\
\text { em cabelo, aguardente, } \\
\text { arroz, pontas de boi }\end{array}$ & $\begin{array}{l}\text { Açúcar branco, } \\
\text { açúcar mascavo, café, } \\
\text { banha, couros em } \\
\text { cabelo, aguardente, } \\
\text { arroz, pontas de boi, } \\
\text { vassouras, }\end{array}$ & $\begin{array}{l}\text { Açúcar branco, açúcar } \\
\text { mascavo, café, banha, } \\
\text { couro em cabelo, arroz }\end{array}$ \\
\hline 1821 & $\begin{array}{l}\text { Açúcar branco, açúcar } \\
\text { mascavo, café, banha, } \\
\text { arroz, couros em cabelo, } \\
\text { ponta de boi }\end{array}$ & $\begin{array}{l}\text { Açúcar branco, açúcar } \\
\text { mascavo, banha, arroz, } \\
\text { couro em cabelo }\end{array}$ & $\begin{array}{l}\text { Açúcar branco, açúcar } \\
\text { mascavo, banha, arroz, } \\
\text { couro em cabelo }\end{array}$ \\
\hline
\end{tabular}


O açúcar branco e mascavo era negociado em quantidade elevadas com o Rio de Janeiro, mas não era isto o que ocorria com outros produtos, como banha de porco, toucinho, café, arroz ou aguardente. Ou seja, as mercadorias coloniais do porto de Santos tinham dois tipos de inserção no comércio atlântico, de acordo com seus tipos. O açúcar tinha uma inserção indireta por meio da praça carioca, mas outros gêneros tinham uma direta, ou seja, havia em Santos um circuito atlântico de mantimentos, excluindo o açúcar, que desembocava nas cidades de Lisboa e Porto.

Em termos de receita de exportação, é certo que Santos angariava mais dinheiro na praça carioca. Em 1810, por exemplo, a receita de exportação de produtos coloniais desta vila marítima para os portos portugueses e para o Rio de Janeiro foram, respectivamente, 11: $276 \$ 700$ e 131:596\$960. ${ }^{36}$ A diversificação da pauta de mercadorias e a elevada quantidade de açúcar explicam esta mais elevada receita de exportação do porto de Santos para o Rio de Janeiro. Algumas mercadorias específicas que seguiam para os portos portugueses, contudo, estavam em quantidades maiores.

A Tabela 5 mostra os valores monetários gerados pelo comércio com os portos portugueses e o Rio de Janeiro, comprovando que o comércio com o Rio de Janeiro gera mais receita, porém ainda é interpretada como irregular, variável a cada ano e somente um ano com valor significativamente superior (1819).

Com os portos cariocas há uma tendência segura de alta do volume dos negócios até 1818, com queda a partir de 1819. Já com os portugueses, é até 1816, um boom em 1818 seguido de uma probabilidade de queda, certamente própria das circunstâncias da independência e do próprio contexto econômico desde a abertura dos portos de diversificação dos parceiros comerciais do Brasil.

Na definição das rotas mercantis específicas e por mercadorias, pôde-se constatar a superioridade dos portos portugueses em relação ao Rio de Janeiro e a um grupo específico de produtos, que não o açúcar, como poderá ser visto mais adiante. De qualquer modo, em boa parte dos períodos, o Porto comprou mais açúcar de Santos do que de Lisboa, que concentrava seus negócios no Rio de Janeiro, como pode ser visto na Tabela 5 .

A Tabela 6 destoa bastante quando diz respeito aos mantimentos. O Porto toma a dianteira em boa parte dos anos, superando Lisboa e Rio de Janeiro na absorção dos mantimentos coloniais de Santos, como foi o caso da banha de porco.

A Tabela 7 que mostra os couros em cabelo serve para confirmar o que Helen Osório já desenvolveu bem: a força do eixo Rio de Janeiro-Rio Grande no circuito do couro com a praça de Lisboa. Em certos momentos, nem há negócios de Santos com o Rio de Janeiro neste setor, assim como com Lisboa. Para o Porto o processo é bem diferente, o que fundamenta a tese de que portos menores situados na costa do Brasil podem ter sido uma possibilidade de acesso dos portos periféricos portugueses às mercadorias de alta demanda.

A Tabela 8 referente à aguardente é interessante por mostrar que os portos platinos - Montevidéu e Buenos Aires - tenderam a absorver este produto proveniente de Santos. A aguardente deste porto, por outro lado, também pode ter sido empregada no tráfico negreiro na região ${ }^{37}$ de Lisboa e Porto, cidades marítimas que

\footnotetext{
${ }^{36}$ Dado recolhido em Mapas de Importação e Exportação do porto de Santos, 1810-1821. Real Junta de Comércio, cx. 448, pct. 1, Arquivo Nacional, Rio de Janeiro.

${ }^{37}$ Alex Borucki, "The Slave Trade to the Río de la Plata. Trans-imperial Networks and Atlantic Warfare, 1777-1812", Colonial Latin American Review, vol. 20, n. 1, 2011, p. 81-107.
} 
terminaram por concorrer e se revezar na condição de primazia na aquisição da aguardente do Brasil.

$\mathrm{O}$ arroz foi em primeiro plano enviado para o Porto, mas o Rio de Janeiro passou a ter no Porto de Iguape, a partir de 1808, com a instalação da Corte, um importante fornecedor deste produto ${ }^{38} \mathrm{o}$ que explica sua menor aquisição em Santos, num contexto em que havia tanta demanda por este gênero, haja vista a expansão de seu mercado consumidor com a migração da família real.

Em 1810 o Rio de Janeiro ainda foi um grande comprador deste gênero no porto de Santos (455 arrobas) em relação aos portos portugueses (250 arrobas). Mas em 1814 a situação já está bastante invertida - 1752 arrobas destinadas aos portos das cidades do Porto e Lisboa, contra 317 arrobas enviadas para o Rio de Janeiro e assim se manteve até 1821.39

Tabela 5. Quantidade em alqueires de açúcar branco exportado pelo porto de Santos para os do Porto/Lisboa e Rio de Janeiro entre 1810 a 1821. Dados levantados em mapas de importação e exportação do porto de Santos, 1810 a 1821. Real Junta de Comércio, caixa 448, pacote 1, Arquivo Nacional, Rio de Janeiro.

\begin{tabular}{|cccc|} 
& Porto & Lisboa & Rio de Janeiro \\
\hline 1810 & 4.715 & - & 94.816 \\
1814 & 6.266 & - & 102.154 \\
1815 & 7.149 & 1.833 & 52.860 \\
1816 & 8.051 & 5.585 & 85.428 \\
1817 & 7.738 & 8.002 & 90.663 \\
1818 & 34.758 & 7.392 & 160.397 \\
1819 & 12.472 & 10.566 & 194.730 \\
1820 & 19.630 & 10.841 & 119.702 \\
\hline 1821 & 16.872 & 3.846 & 104.347 \\
\hline
\end{tabular}

Tabela 6. Quantidade em arrobas de banha de porco exportadas pelo porto de Santos para os do Porto/Lisboa e Rio de Janeiro entre 1810 a 1821. Mapas de importação e exportação do porto de Santos, Fundo Real Junta de Comércio, caixa 448, pacote 1, Arquivo Nacional, Arquivo Nacional, Rio de Janeiro, de 1809 a 1821.

\begin{tabular}{lccc} 
& Porto & Lisboa & Rio de Janeiro \\
\hline 1810 & 200 & - & - \\
\hline 1814 & 5.805 & 100 & 1.106 \\
\hline 1815 & 2.705 & - & 909 \\
1816 & 2.804 & 172 & 139 \\
\hline 1817 & 1.416 & 82 & 565 \\
1818 & 10.450 & - & 139 \\
1819 & 3.395 & 699 & 93 \\
\hline 1820 & 1.851 & - & 256 \\
\hline 1821 & 1.157 & 66 & 916 \\
\hline
\end{tabular}

${ }^{38}$ Agnaldo Valentin, Comércio marítimo de abastecimento: o porto de Iguape (São Paulo), 1798-1880, Disponível em: http://www.registro.unesp.br/sites/museu/basededados/arquivos/00000313.pdf, p. 10, acesso em 10 de março de 2010.

${ }^{39}$ Dados recolhidos em Mapas de Importação e Exportação do porto de Santos. Fundo Real Junta de Comércio, cx. 448, pct. 1, Arquivo Nacional, Rio de Janeiro, 1809-1821. 
No entanto, o café indica uma realidade mais oscilatória, com os três portos concorrendo por um produto que na realidade vive os primórdios da sua inserção no mercado consumidor, para atingir mais adiante no século 19 a liderança das exportações do Brasil. Em 1814 os portos portugueses adquiriram 390 arrobas de café do porto de Santos e o Rio de Janeiro um valor bem mais elevado: 948 arrobas. Em 1818 uma inversão: portos portugueses consumiram 387 arrobas e o Rio de Janeiro apenas 103 arrobas. ${ }^{40}$

Os dados sistematizados e apresentados até o momento servem para, além de fundamentar as ideias apontadas, mostrar que, ao pesquisar sobre o comércio nos impérios modernos, pode ser interessante uma incursão no interior das embarcações para se analisar cada mercadoria por seus montantes negociados. As

Tabela 7. Quantidades de couro em cabelo exportado pelo porto de Santos para os do Porto/Lisboa e Rio de Janeiro entre 1810 a 1821. Mapas de importação e exportação do porto de Santos. Fundo Real Junta de Comércio, caixa 448, pacote 1, Arquivo Nacional, Rio de Janeiro, 1809-1821.

\begin{tabular}{|cccc|} 
& Porto & Lisboa & Rio de Janeiro \\
\hline 1810 & 610 & - & 963 \\
1814 & 39 & - & - \\
1815 & 4.230 & 605 & - \\
1816 & 5.840 & 2.028 & - \\
1817 & 2.239 & 1.532 & - \\
1818 & 577 & 864 & 347 \\
1819 & - & 1.241 & 150 \\
1820 & 4.054 & 1.970 & 474 \\
1821 & 1.918 & 764 & 2.480 \\
\hline
\end{tabular}

Tabela 8. Quantidades de pipas aguardentes exportadas pelo porto de Santos para os do Porto/Lisboa e Rio de Janeiro entre 1810 e 1820. Mapas de importação e exportação do porto de Santos. Fundo Real Junta de Comércio, caixa 448, pacote 1, Arquivo Nacional, Rio de Janeiro, 1809-1821.

\begin{tabular}{|ccccc|} 
& Porto & Lisboa & Rio de Janeiro & Portos platinos \\
\hline 1810 & 20 & - & 01 & 29 \\
1814 & 139 & 13 & 68 & 38 \\
1815 & 1 & - & 01 & 26 \\
1816 & 2 & 12 & 0 & 05 \\
1817 & - & & 0 & 4 \\
1818 & 103 & 8 & 1 & 6 \\
1819 & 13 & 185 & 0 & 10 \\
1820 & 76 & 95 & 0 & 20 \\
\hline 1821 & - & - & - & - \\
\hline
\end{tabular}

40Dados recolhidos em Mapas de Importação e Exportação do porto de Santos. Fundo Real Junta de Comércio, cx. 448, pct. 1, Arquivo Nacional, Rio de Janeiro, 1809-1821; Alexandre Valentim, Os sentidos do Império: questão nacional e questão colonial na crise do Antigo Regime Português. Lisboa, Edições Afrontamento, 1993, p. 42. 
informações sobre os totais de exportação dos mapas portuários, portanto, são poucas para uma pesquisa sobre tal temática.

Pesquisas analisando números de embarcações que dão entrada em portos periféricos podem concluir que um porto pequeno, como o de Santos, não participava significativamente das rotas do Reino ou tinha uma participação restrita a mercadorias principais do mercado internacional, como o açúcar.

A análise por cada mercadoria, pois cada uma compreendia um circuito, leva a um quadro mais diversificado. Isto não quer dizer que o porto de Santos era um mero exportador de mercadorias coloniais, ele teve um importante papel no mercado interno de cabotagem, com gêneros perecíveis, como queijos e doces. ${ }^{41}$ Mantimentos como a banha de porco, o couro em cabelo, a aguardente e o arroz são muito particulares e dizem respeito apenas a estes circuitos, que não eram exclusivamente internos e subordinados ao Rio de Janeiro.

Certamente e por esses dados exclusivamente relativos ao movimento das mercadorias, neste momento não estão sendo conceituados os negociantes, mas são a peça essencial que movimenta o sistema, os negociantes que atuavam no porto de Santos tinham uma margem de autonomia para negociar com os do Reino ou do Rio de Janeiro ou mesmo dos portos platinos.

\section{Um subsistema de captação de mantimentos coloniais}

Qual a procedência dos mantimentos coloniais que o porto de Santos negociava nas cidades de Porto, Lisboa, Rio de Janeiro e portos platinos? O açúcar, como já comprovado por estudo clássico e outro mais recente vinha do chamado quadrilátero do açúcar, de municípios serra acima, como Sorocaba, Itu, Porto Feliz, Piracicaba, Mojimirim, Jundiaí e Campinas. ${ }^{42}$

Os mantimentos secos e molhados tinham pelo menos quatro procedências: da própria vila de Santos, das unidades produtivas de serra acima, do termo da cidade de São Paulo, das vilas novas, como Nazareth, Atibaia e Bragança, e da costa da capitania.

Com o intuito de conceituar um subsistema portuário, portanto, uma malha mercantil formada por portos pequenos que tinham Santos como polo, este texto tratou apenas da procedência costeira dos mantimentos. ${ }^{43}$

Na realidade, os mapas de exportação que formam a principal base empírica dos argumentos deste trabalho permitem indicações seguras apenas das movimentações costeira e atlântica das mercadorias. Qualquer consideração sobre a movimentação interna e serra acima dos produtos será apenas inferência.

\footnotetext{
${ }^{41}$ Denise A. Soares Moura, “O comércio colonial e suas relações complementares: Santos, Bahia e Pernambuco, 1765-1822”. In: Carla Mary S. Oliveira, Mozart Vergetti Menezes, Regina Célia Gonçalves, Ensaios sobre a América Portuguesa, Universidade Federal de Pernambuco, João Pessoa/Paraíba, Editora UFPE, 2009, p. 181-196. ${ }^{42}$ Para Maria Theresa Schorer Petrone, o quadrilátero correspondia às vilas de Sorocaba, Piracicaba, Mogi-Guaçu e Jundiaí. Cf. Maria Thereza Schorer Petrone, A lavoura canavieira em São Paulo. Expansão e declínio (17651888), São Paulo, Difusão Europeia do Livro, 1968, p. 41. Pablo Oller Mont Serrat, Dilemas e conflitos na São Paulo restaurada: formação e consolidação da agricultura exportadora (1765-1802), Dissertação (Mestrado) Faculdade de Filosofia, Letras e Ciências Humanas da Universidade de São Paulo, São Paulo, 2007, p. 112.

${ }^{43}$ As outras procedências foram documentadas e discutidas em outros textos. Cf. Denise A. Soares Moura, "Poder local e o funcionamento do comércio vicinal na cidade de São Paulo (1765-1822)", História. Universidade Estadual Paulista “Júlio de Mesquita Filho”, vol. 24, n. 2, 2005, p. 265-290; Denise A. Soares Moura, Região, relações de poder e circuitos mercantis em São Paulo. Revista Saeculum, n. 14, João Pessoa, Universitária da Universidade Federal de Paraíba, 2006
} 
Porém, deve-se destacar que, a partir de 1815 e conforme dados levantados nos Mapas de Importação e Exportação do porto de Santos, houve uma redução da captação de mantimentos na costa da capitania de São Paulo. Neste aspecto, o fim da era de governadores, como Bernardo José de Lorena ou Antonio José da França e Horta, os quais aplicaram políticas para concentrar as exportações dos portos menores da capitania em Santos ${ }^{44}$ impactou negativamente em sua importação costeira. Contudo, os números da exportação dos mesmos produtos permaneceram muito superiores.

Se a captação costeira dessas mercadorias, no porto de Santos, tendeu a ser inferior a da exportação, certamente essas mercadorias estavam sendo adquiridas nos circuitos mercantis terrestres, o que significa que o caminho do mar estava se fortalecendo no escoamento de produtos para a vila de Santos.

O contrato público da passagem do Cubatão de Santos, direção obrigatória de quem seguia da cidade de São Paulo para Santos, vivia uma tendência de inflação de seus valores, desde o final do século XVIII, ${ }^{45}$ portanto havia uma intensificação da circulação interna de mercadorias destinada à esta vila marítima.

A queda na captação costeira do porto de Santos deve ser explicada pela interpretação de Agnaldo Valentim. Segundo o mesmo, com a vinda da Família Real para o Brasil, este porto perdeu a primazia no comércio costeiro, condição até então sustentada pela política específica de governadores que tinham interesse em intensificar sua relação mercantil com os do reino. Com a transferência da Família Real para o Brasil e o incremento do mercado consumidor do Rio de Janeiro, a política mercantil tendeu a uma liberalização e à defesa do fim dos monopólios, cujo ponto alto foi, sem dúvida, a abertura dos portos.

Diante da nova realidade de maior liberdade de comércio interna e externamente, o porto de Santos, para continuar atendendo às demandas por mercadorias coloniais específicas dos portos do Reino e do continente, pode ter completado a quantidade de mercadorias que exportava internamente por meio da produção da própria vila, da cidade e seu termo, serra acima e das vilas próximas? Se for de outro modo, como explicar uma quantidade de exportação de certos mantimentos bem superior ao que era captado na costa, especialmente a partir de 1815?

Desde 1790 o governador Bernardo José de Lorena vinha estimulando a produção de mantimentos na capitania, visando à exportação marítima pelo porto de Santos. Em ofício aos capitães-mores da capitania, o governador informava:

presentemente acha-se estabelecido um comércio direto para a Europa do Porto de Santos. Por estas razões devem vocês empregar o seu cuidado todo, em promover a cultura dos gêneros mais próprios para aquele comércio, como são principalmente: açúcar, café, Goma, anil, arroz, e algodão. ${ }^{46}$

Este incentivo à produção interna da capitania recaiu também sobre as vilas costeiras. Paranaguá, juntamente com Iguape, ambas na capitania de São Paulo,

\footnotetext{
${ }^{44}$ Renato Mattos, Política, administração e negócios na capitania de São Paulo e sua inserção nas relações mercantis do Império português (1788-1808), Dissertação (Mestrado) - Faculdade de Filosofia, Letras e Ciências Humanas da Universidade de São Paulo, São Paulo, 2009; Ana Paula Medici, Administrando conflitos: o exercício do poder e os interesses mercantis na capitania/província de São Paulo (1765-1822), Tese (Doutorado) Faculdade de Filosofia, Letras e Ciências Humanas da Universidade de São Paulo, São Paulo, 2010.

${ }^{45}$ Ana Paula Medici, Ibidem, p. 93.

${ }^{46}$ Ofício do Governador Bernado José de Lorena ao capitães-mor, Documentos Interessantes para a História e Costumes de São Paulo. V. XLVI, p. 67-68, 26/02/1790.
} 
foram uma das principais na produção de arroz e farinha ${ }^{47}$. Em 1794, o sargentomor de Paranaguá foi notificado para que impedisse que qualquer embarcação partisse daquele porto se não fosse com destino certo para o porto de Santos,

ainda mesmo aquela ou aquelas que forem a essa vila somente a carregar madeiras, pois que debaixo desse indulto levam disfarçadamente para fora da capitania arrozes e outros gêneros tendentes ao comércio. ${ }^{48}$

A imposição de restrições ao comércio dos portos menores, obrigando-os a subordinar seus negócios a Santos coincidiu com a presença de governadores que não somente tiveram vínculos mercantis com portos portugueses, como também expressaram vivamente o projeto da coroa portuguesa de fortalecer as relações mercantis com a capitania de São Paulo.$^{49}$ Se não fossem suas capacidades de bem traduzirem os anseios do império numa conjuntura de crise, teriam seus governos se escorado apenas em interesses mercantis pessoais?

Desde o governo de Antonio Luis de Souza Botelho Mourão, em 1768, havia forças políticas e mercantis que tentavam fazer prevalecer o comércio direto de Santos com Lisboa. Mas o poder de pressão dos agentes relacionados ao comércio interno e aos contratos públicos de passagens e dos dízimos ou à liberdade de comércio pode ser percebido em sua capacidade de, em cooperação com a câmara da cidade de São Paulo, malograr o projeto do governador, apoiado por vários negociantes de Santos e de São Paulo, de formar uma companhia de comércio direto com Lisboa a partir de Santos. ${ }^{50}$

Os interesses ligados ao comércio interno ou mais livre sempre persistiram, ora apenas teimando em cumprir as determinações que obrigavam ao comércio exclusivo com o porto de Santos, ora manifestando-se organizadamente, como fizeram alguns produtores e negociantes de Paranaguá. Em 1806, foi endereçada uma carta diretamente ao rei reclamando da proibição imposta pelo governador Franca e Horta de comercializarem livremente na costa os mantimentos que produziam.

Em interrogatório prestado ao juiz de fora da vila de Santos, Antonio Calos Ribeiro de Andrada e Silva, os camaristas denunciaram o monopólio exercido pelos negociantes de Santos sobre o comércio costeiro da capitania. ${ }^{51}$ Tais negociantes, portanto, tiravam proveito de uma conjuntura do império, em que os governadores escalados para a capitania de São Paulo aplicavam políticas favorecendo o porto de Santos para ser um centro receptor de mercadorias coloniais na costa.

No entanto, a chegada da família real ao Rio de Janeiro alterou bastante esse quadro. Os negócios fixados na relação Santos-portos do reino, que até então eram favorecidos pelas pressões para a concentração da captação de mercadorias no porto de Santos, não encontraram mais justificativa nas

\footnotetext{
${ }^{47}$ Caroline Silva Severino, A dinâmica do poder e da autoridade na Comarca de Paranaguá e Curitiba (1765-1822), Dissertação (Mestrado), Universidade Estadual Paulista “Júlio de Mesquita Filho” (Unesp), Franca, 2009.

${ }^{48}$ Para o sargento-mor de Paranaguá Francisco José Monteiro. Documentos interessantes para a história e costumes de São Paulo, v. XLVI, 30/03/1794, p. 256.

${ }^{49}$ Ana Paula Medici, Administrando conflitos: o exercício do poder e os interesses mercantis na capitania/ província de São Paulo (1765-1822), Tese (Doutorado) - Faculdade de Filosofia, Letras e Ciências Humanas da Universidade de São Paulo, São Paulo, 2010. p. 127-132.

${ }^{50}$ Atas da Câmara, vol. 15, 13/01/1768, p. 326-335.

${ }^{51}$ Alfândega. Santos. Arquivo Público do Estado, ordem 236, caixa 10, documento 10-06-50, 1806.
} 
políticas régias e nos portos até então submetidos às pressões de Santos, passando a negociar livremente seus produtos direto com a praça do Rio.

Em 1808, Dom João VI revogou o ato do capitão-general Bernardo José de Lorena, que proibia a navegação de portos da capitania diretamente com o Rio de Janeiro. Na ocasião, as embarcações tinham de passar pelo porto de Santos. Agnaldo Valentim mostrou os efeitos desta medida seis anos depois, a partir de 1814, e para o caso do circuito do arroz. Deste modo, Santos perdeu a primazia do arroz iguapense em favor do Rio de Janeiro. ${ }^{52}$

A queda na captação costeira do porto de Santos entre seis a sete anos após a chegada da Família Real pode ser percebida em relação a outros produtos que alcançaram níveis de exportação para os portos portugueses superiores aos do Rio de Janeiro, como indicam os dados reunidos nos mapas de importação.

Entre 1814-1816 o porto de Santos importou maior quantidade de couros em cabelo de Buenos Aires (12.365) do que do Rio Grande (1.100). ${ }^{53}$ Estes dados sugerem que o produto re-exportado por Santos para a cidade do Porto era proveniente de Buenos Aires. O couro do Rio Grande estava fortemente vinculado à praça do Rio de Janeiro, o que pode ter favorecido a formação de um circuito platino do couro, ligando Santos a Buenos Aires.

A partir de 1821 Santos pode ter recuperado sua capacidade de captar arroz na costa em 1821. De 1819 a 1821, das várias cidades da costa da capitania foram importados um total de 120, 870 e 2.030 arrobas. ${ }^{54}$ Mas apenas uma pesquisa que prosseguisse no contexto da independência poderia considerar com mais segurança se realmente ocorreu uma tendência de recuperação do porto de Santos da sua antiga condição de polo de captação de mercadorias coloniais na costa, no período anterior ao do estabelecimento da Família Real no Brasil e nos poucos anos posteriores.

O circuito da banha de porco é bastante particular e aparecia com boa exportação para Porto e Lisboa, como pode ser visto acima. Provavelmente sua procedência, em grande medida, não era costeira, mas interna. Caio Prado Jr. chamou atenção para a importância da indústria dos derivados do porco no período colonial e mesmo posterior, pois este animal doméstico tinha baixos custos de criação e manutenção. Logo, este é um campo que merece ser investigado e conceituado.

Para finalizar pode-se pensar em uma especialização de circuitos de mercadorias nas costas Norte e Sul da capitania de São Paulo em direção ao porto de Santos. Ou seja, o Sul foi um fornecedor de arroz e as vilas marítimas do norte abasteceram Santos com café e aguardente. Em virtude disto esta região em especial pode ter sido marcada por muitas contradições e conflitos internos, devido a sua proximidade física com o Rio de Janeiro e à subordinação administrativa a São Paulo. ${ }^{55}$

\footnotetext{
${ }^{52}$ Agnaldo Valentim, Comércio marítimo de abastecimento: o porto de Iguape (São Paulo), 1798-1880, Disponível em: http://www.registro.unesp.br/sites/museu/basededados/arquivos/00000313.pdf, acesso em 10 de março de 2010, p. 10-11.

${ }^{53}$ Mapas de Importação e Exportação do porto de Santos. Fundo Real Junta de Comércio, cx. 448, pct. 1, Arquivo Nacional, Rio de Janeiro, 1809-1821.

${ }^{54}$ Dados recolhidos em Mapas de Importação e Exportação do porto de Santos. Fundo Real Junta de Comércio, cx. 448, pct. 1, Arquivo Nacional, Rio de Janeiro, 1809-1821.

${ }^{55}$ Filipe Garrido vem desenvolvendo pesquisa de mestrado sobre este assunto no Programa de pós-graduação da Faculdade de Ciências Humanas e Sociais da Universidade Estadual Paulista "Júlio de Mesquita Filho".
} 


\section{Conclusões}

Os dados dos mapas de importação e exportação do porto de Santos entre 1810-1821 possibilitam a conceituação das atividades mercantis costeira e atlântica de um porto periférico situado na costa sul do Brasil

O porto de Santos formou um subsistema no contexto maior do sistema mercantil do império português, pois era menor, periférico em relação aos principais, como Rio de Janeiro, Salvador e Recife; possuía um índice bem mais modesto de movimentação de navios de procedência e destino atlântico, movimentava também um número de mercadorias coloniais menor, mas tinha um tipo de inserção e função no comércio colonial do período. Ele funcionou como um complementador da demanda por produtos coloniais diversificados, especialmente de portos portugueses ou mesmo secundários, como a cidade marítima do Porto. O Rio de Janeiro, portanto, não foi um centralizador de sua movimentação mercantil, mesmo com a ampliação do mercado consumidor carioca desde a transmigração da Família Real.

A instalação da corte no Rio, contudo, bem como as tendências liberalizantes da economia deste período, tenderam a alterar, desde pelo menos 1815 , sua condição anterior de polo de capitação de mercadorias na costa sul do continente. Ainda assim, seus níveis de exportação para os portos do Reino se mantiveram, o que sugere o fortalecimento dos circuitos mercantis internos terrestres e especialmente do caminho do mar.

Essa condição de subsistema do porto de Santos, desempenhando papéis nos mercados atlântico e costeiro, pode ter alimentado um quadro de contradições e disputas mercantis nesta própria vila marítima. Uma pesquisa que conceituasse os grupos que atuavam neste porto talvez pudesse revelar uma realidade social tão complexa e diversificada como era a mercantil. 